\title{
Forms of Providing and Financing Long-Term Care in OECD Countries
}

\author{
Renáta Halásková ${ }^{1}$, Pavel Bednářํㄹ, Martina Halásková ${ }^{3}$
}

\begin{abstract}
Long-term care is being prioritised due to population ageing, and hand in hand with the development of professional provision of long-term care, public expenditures will be increasing. Mainly countries with a sharp increase in the number of people aged $80+$ will have to address the sustainability of long-term care systems and the procurement of relevant services. This paper aims to evaluate the forms of provision and financing of long-term care in selected OECD countries. Provision and funding of longterm care in terms of a formal system are assessed based on selected criteria using analytical methods (principal component analysis and TwoStep cluster analysis). Results of the evaluation carried out in 2008 and 2013 by means of the selected indicators of longterm care, using TwoStep cluster analysis, confirmed both similar as well as different approaches to the provision and financing of long-term care in the analysed countries. The most marked differences in the provision of care based on indicators LTC recipients aged 65+ and LTC recipients in institutions as a percentage of total LTC recipients were found between the first cluster (Australia and Korea with the highest share of LTC recipients) and the second cluster (Czech Republic, Estonia, with the lowest share of LTC recipients). In financing of long-term care (LTC expenditures on institutions as a percentage of total LTC expenditures), the most significant differences were observed between the first (Australia, Korea, with the largest share of LTC expenditures on institutions) and third cluster (mainly Nordic countries, with the lowest share of LTC expenditures on institutions of total LTC expenditures).
\end{abstract}

Key words: Long-term care, long-term care expenditure, OECD countries, provision of care, recipients of care

JEL Classification: H41, H51, H75

Received: 1 December 2016/Accepted: 2 May 2017 / Sent for Publication: 8 June 2017

\footnotetext{
${ }^{1}$ College of Logistics in Přerov, Palackého 1381/25, 75002 Přerov, Czech Republic, e-mail: renata.halaskova@vslg.cz

${ }^{2}$ Tomas Bata University in Zlín, Faculty of Management and Economics, Department of Regional Development, Public Sector Administration and Law, Mostní 5139, Zlín, 760 01, Czech Republic, e-mail: bednar@fame.utb.cz

${ }^{3}$ VŠB-Technical University of Ostrava, Faculty of Economics, Department of Public Economics, Sokolská tř́́da 33, 70121 Ostrava, Czech Republic, e-mail: martina.halaskova @vsb,cz
}

(c) 2017 by the authors; licensee Review of Economic Perspectives / Národohospodářský obzor, Masaryk University, Faculty of Economics and Administration, Brno, Czech Republic. This article is an open access article distributed under the terms and conditions of the Creative Commons Attribution 3.0 license, Attribution - Non Commercial - No Derivatives. 


\section{Introduction}

Long-term care is moving up in the political agenda of many countries, and its significance is bound to rise, particularly in connection with the ageing of the population (Válková, Kojesová \& Holmerová, 2010, Colombo et al., 2011, Gavurová \& Šoltés, 2016, Rowles \& Teaster 2016). Long-term care services refer to the organisation and delivery of a broad range of services and assistance to people who are limited in their ability to function independently, on a daily basis and over an extended period of time. There are two complementary components of this definition: firstly, care continues over a long time period, and secondly, care is usually provided as an integrated programme across various components of service. The services may be provided in a variety of settings, including institutional, residential or home care. Long-term care needs are most prevalent for the oldest age groups (OECD, 2007, Colombo et al., 2011).

Long-term care has already been discussed in connection with the changes, development and trends of long-term care (Anttonen \& Sipila, 1996, Pavolini \& Ranci, 2008, Österle, 2010, Colombo et al., 2011, Brennan et al., 2012, Deusdad, Pace \& Anttonen, 2016), quality assessment and long-term care service efficiency (OECD, 2005, Průša, 2011, Dandi \& Casanova, 2012, Mot et al., 2012) or the approaches to and capabilities of long-term care financing (Barr, 2010, Fernandez \& Forder, 2010, Kraus et al., 2010, Colombo et al., 2011, Průša, 2011, Repková et al. 2011, Geerts, Willemé \& Mot, 2012, Rodrigues, 2015).

This paper aims to define long-term care and evaluate forms of providing and financing long-term care based on the volume and structure of long-term care expenditures in selected OECD countries. Along with the objective, the subject of investigation is also defined: a narrow view on health and long-term care. Quantitative analysis presumes a selection of long-term care tools. In connection with the provision and financing of long-term care, this paper focuses on selected indicators of expenditures and recipients of long-term care. The evaluation is based on the assumption that OECD countries apply different approaches to providing and financing long-term care.

\section{Theoretical background and literature review}

Long-term care (LTC) is a set of services needed by people with long-term limited selfsufficiency. International institutions (OECD, Eurostat, WHO) define long-term care as a range of services required by persons with a reduced degree of functional capacity (physical or cognitive) and who are consequently dependent on help with basic and/or instrumental activities of daily living (ADL) for an extended period of time. Basic Activities of Daily Living (ADL) or personal care services are frequently provided in combination with help with basic medical services such as nursing care, prevention, rehabilitation or services of palliative care. Instrumental Activities of Daily Living (IADL) or assistance care services are mostly linked to home help (OECD, 2005, Colombo \& al., 2011, European Commission, 2011, European Commission, 2015).

OECD highlights the necessity to distinguish between health care on the one hand and to define long-term care with respect to other services (social services) on the other. As OECD (2005), OECD (2007), European Commission (2009), Válková, Kojesová \& Holmerová (2010) argue, long-term care services comprise two types of services, de- 
pending on the classification of systems of health accounts (SHA): 1) services of longterm nursing care, which can be considered a component to LTC or long-term medical care. This mainly concerns aid in the elementary activities of daily life (eating, bathing, washing, basic mobility). This care is usually provided along with other medical services. 2) social services of long-term care, represented by social services for the ill or disabled. These are generally focused on aid in the instrumental activities of daily life (IADL) of those in need.

Long-term care can be provided in different settings: at home and in a community, or in various types of institutions, including nursing homes and long-stay hospitals. Mixed forms of residential care and (internally or externally provided) care services exist in the form of assisted living facilities, sheltered housing, etc. (OECD, 2005, OECD, 2007, European Commission, 2009, European Commission, 2011, Repková at al., 2011). According to European Commission (2011, p. 244-245) „Services at home include services provided by external home care providers, both public and private, in a person's private home on a long-lasting basis. Also included are services received on a day-case basis or in the form of short-term stays in institutions, in the form of respite care. Services in institutions include services provided to people with moderate to severe functional restrictions who live permanently or for an extended period of time (usually for six months or longer) in specially designed institutions, or in a hospital-like setting where the predominant service component is long-term care, although this may frequently be combined with other services (basic medical services, social activities, etc.). In these cases, eligibility is often explicitly assessed and defined by the level (severity) of dependency and the level of care needs". According to European Commission (2009), Colombo et al. (2011), European Commission (2015), long-term care is delivered informally (by families and friends) and formally (by care assistants who are paid under some form of employment contract). Formal care is given at home or in an institution (such as care centres and nursing homes). Cash benefits are payments that can be used to purchase formal care at home or in an institution or which can be paid to informal caregivers as income support.

In papers by Muiser \& Carrin (2007), Fernandez \& Forder (2010), Mertl (2010), Colombo et al. (2011), Průša (2011), Repková et al. (2011), Rodrigues (2015) and others, systems of long-term care are dealt with in connection with forms of financing and financial sustainability.

A study by Rodrigues (2015) presents an overview of different conceptual models of financing LTC; scope and depth of coverage of LTC systems; discussed also are new forms of cost sharing within and between generations and the coordination of LTC with systems of healthcare and pensions. Colombo et al. (2011) defines three forms of financing long-term care - universal coverage within a single programme, mixed systems, and means-tested safety-net schemes - using an example of 31 OECD countries. Concerning universal coverage LTC within a single programme, three sub-models can be distinguished: tax-based models, public long-term care insurance models, personal care and nursing care through the health system. Under mixed systems, LTC coverage is provided through a mix of different universal programmes and benefits operating alongside one another, or a mix of universal and means-tested LTC entitlements. Under means-tested schemes, LTC coverage is provided through safety-net programmes. This 
approach offers protection to those individuals otherwise unable to pay for care themselves.

Repková et al. (2011, p. 139-140) argues that: "Long-term care services draw resources from the system of health and social care. Each country therefore uses different financial resources, financing and principles of availability and budgets in LTC, which vary according to the nature of the services supplied. In European countries, health care is usually provided in terms of a 'compulsory' universal health insurance (generally financed from mandatory taxes or social-insurance contributions) in order to be complex as far as population coverage is concerned, and is free of charge at the time of the provision. On the other hand, social-care services are financed from tax revenues and users' payments, and are subject to testing of revenues that consider social conditions of the user and the family."

The wider context of long-term care expenditures and their definition is presented in studies by OECD 2007, European Commission, 2009, European Commission, 2011. Clear definitions and a harmonisation of the boundaries between health spending and social LTC spending help ensure comprehensive and internationally comparable data on the total expenditure on health.

Figure 1 The wider context of Long-term care expenditure

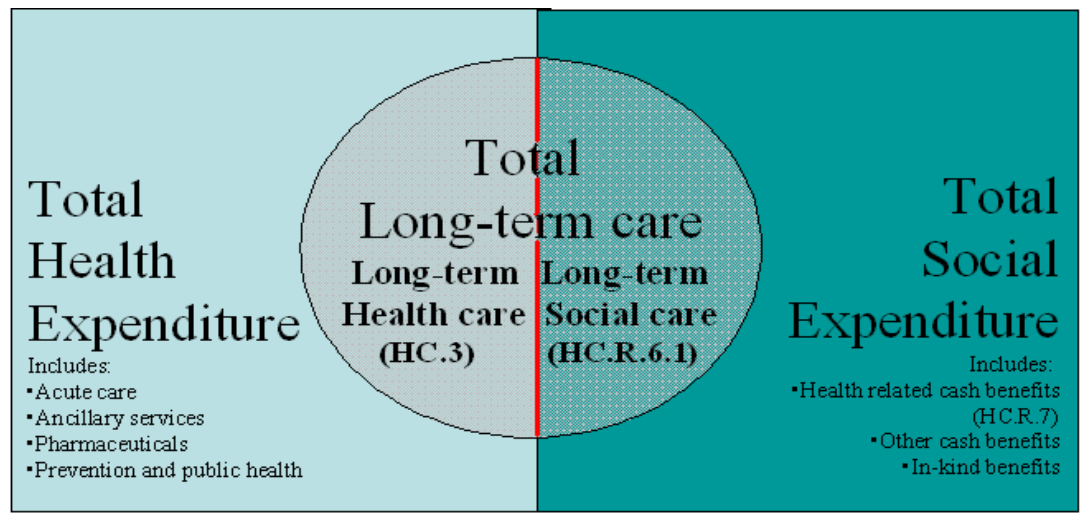

Source: $\operatorname{OECD}(2007, p .5)$

Total long-term care spending is calculated, according to OECD (2007), as the sum of services of long-term health care and social services of long-term care (figure 1). Services of long-term health care are included in the total expenditure on health. In the current guidelines, the following are included under HC.3: palliative care, long-term nursing care, personal care services, and services in support of informal (family) care. Services of long-term nursing care (HC.3) consist of three subcategories: In-patient long-term nursing care (HC.3.1), Day cases of long-term nursing care (HC.3.2) and Long-term nursing care: home care (HC.3.3). The categories HC.3.1 + HC.3.2 represent long-term care expenditures on services of institutional care, and category HC.3.3 represents long-term expenditures on home-care services. Social services of long-term care are excluded from the total expenditure on health, but included in total LTC expenditure. 
In the current guidelines, the following are included under HC.R.6.1: home help and care assistance, residential care services, and other social services.

\section{Data and Methods}

This paper drew from data in the OECD database. Due to the limited availability of data for the particular long-term care indicators in OECD statistics, the years 2008 and 2013 were selected as the default years (the latest OECD data at the time of this paper's writing). The subject of quantitative analysis, the selected set of 13 OECD countries, comprises: AU-Australia, CZ-Czech Republic, DK-Denmark, EE-Estonia, FI-Finland, DEGermany, HU-Hungary, KR-Korea, LU-Luxembourg, NL-Netherlands, NO-Norway, SE-Sweden, CH-Switzerland. Countries were selected on a deliberate basis with the aim to ensure heterogeneity from the perspective of the observed indicators/variables, where countries with varying degrees of the provision and forms of financing of long-term care are represented. One selection criterion was the availability of comparative OECD data on long-term care for the years 2008 and 2013. Having consulted professional resources, the authors made use of content analysis when providing the theoretical framework of the issue in question, applying analytical methods, comparative method, principal component analysis (PCA), and TwoStep cluster analysis in the empirical part, and synthesis and partial induction in the process of reaching conclusions.

Principal component analysis (PCA) is a statistical method that explains or describes the dispersion of manifest or measured variables. The aim of the paper is therefore to obtain the most of the original piece of information using a minimum amount of latent variables (Meloun \& Militský, 2004). This method was selected in order to reveal the correlation between the observed variables of long-term care in years 2008 and 2013, by use of correlation analysis, $\mathrm{p}<0.05$, see Table 1

Table 1 Intercorrelation matrix of long-term care variables in the selected OECD Countries for 2008 and 2013

\begin{tabular}{ccccccc}
\multicolumn{7}{c}{ Long-term care variables } \\
\hline A & A & B & C & D & E & $\mathrm{F}$ \\
B & 1 & & & & & \\
C & $0.476^{* a}$ & 1 & & & & \\
D & $-0.714^{* *}$ & -0.314 & 1 & & & \\
E & -0.254 & 0.172 & 0.253 & 1 & 1 & 1 \\
F & 0,039 & 0.309 & -0.096 & $0.493^{*}$ & -0.331 & 1 \\
\hline
\end{tabular}

Note: A) Total LTC expenditure (HC.3.1+ HC.R.6.1) as a percentage of GDP, B) LTC expenditure (PLI, USD) per one LTC recipient, C) LTC expenditure on institutions as a percentage of total LTC expenditure, D) Total number of LTC recipients aged 65+ as a percentage of total LTC recipients, E) LTC recipients in institutions as a percentage of total recipients, F) Total LTC recipients as a percentage of the population $a * p<0.05$, **p<0.01.

Source: authors based on OECD (2015b), OECD (2016a) 
Principal components were extracted using the Kaiser rule for eigenvalues, which recommends keeping only those components reaching a value larger than 1 . The principal components were determined using the correlation matrix. Based on an assessment of the reached explanation of total variability, the output with four variables proved to be the best, with total variability reaching $82.2 \%$. The included variables were: Total LTC expenditure as a percentage of GDP, LTC expenditure on institutions as a percentage of total LTC expenditure, Total number of LTC recipients aged $65+$ as a percentage of total LTC recipients, LTC recipients in institutions as a percentage of total recipients. The outcome of the PCA served as a tool for further analysis using cluster analysis, according to Mazzocchi (2008). For a better illustration of the results of the cluster analysis, with respect to the number of PCA variables and accounting for total variability, original values of the above-mentioned variables in the PCA were used in the following cluster analysis.

For the following evaluation of similarities and differences between OECD countries by selected indicators of long-term care, TwoStep cluster analysis was applied. One thing all cluster analysis approaches have in common is that they search for similarities and differences, compiling data into sensible clusters, where examples belonging to one cluster are most similar to one another, and least similar to those in other clusters (Koštál 2013). TwoStep cluster analysis combines non-hierarchical and hierarchical cluster analyses. Initially, non-hierarchical clusters are generated, reducing the complex set to a small set of k-means clusters. Using a smaller set, up to 100-200 examples, these clusters are subsequently processed through hierarchical analysis, which was also applied in this very case due to there being 13 countries with panel data over two time periods, i.e. 26 examples in total. TwoStep cluster analysis is particularly useful in cases when no specific number of clusters is presupposed and when scale variables are used both of these conditions are met in the present analysis. To determine the automatic number of clusters, Euklidinan distance was applied in the examples, using the Akaike information criterion, which is based on goodness-of-fit measures (Mazzocchi 2008). The Shapiro-Wilk test confirmed that variables entering the process of cluster analysis meet the conditions of normality $(\mathrm{p}<0.05)$, except for the variable Total number of LTC recipients aged $65+$ as a percentage of total LTC recipients. However, based on an examination of the detrended normal Q-Q plot, it was concluded that deviation from normality is insignificant both in minimum as well as maximum observed values, absolute maximum deviations reach 0.70 .

The quality of clusters in TwoStep cluster analysis is measured by the Silhouette measure of cohesion and separation (Košt'ál, 2013). The Silhouette measure of cohesion and separation is defined as the mean of $\psi$ i values, i.e.

$$
\psi=\frac{\sum_{i=1}^{n} \psi_{i}}{n}
$$

The value can range from -1 to 1 . If the average distance of an $i$-th object from other objects in the same cluster is lower than the average distance of objects from any other given cluster, the coefficient reaches positive values. The higher the value, the more compact the clusters. With values below 0.2 , the division of objects into clusters is con- 
sidered poor, fair in values ranging from 0.2 to 0.5 , and good in values greater than 0.5 . The highest value of the coefficient from the given interval, can serve to determine the optimal number of clusters ( ̌̌ezanková \& Löster, 2013, p. 141-142).

A power scale with exponent 0.5 on axis y was applied for proper visibility of values of the variable Total LTC expenditure as a percentage of GDP in the box plot that was used to graphically examine results of the cluster analysis.

\section{Results}

This part presents the results of the provision and financing of long-term care in the selected OECD countries in 2008 and 2013. The paper firstly focuses on 1) the evaluation of total expenditures on health and long-term care, 2) the analysis of the structure of expenditures and recipients of long-term care, and 3) the similarities and differences between the selected OECD countries by selected indicators of long-term care using TwoStep cluster analysis.

Evaluation of total expenditures on health care and on long-term care in selected OECD countries

In connection with the financial capabilities and priorities of OECD countries in the years 2008 and 2013, the present analysis first provides an analysis of the relationships between total expenditures on health-care and total expenditures on long-term care.

Figure 2 Total expenditure on health care and long-term care expenditure in the selected OECD Countries for 2008 and 2013

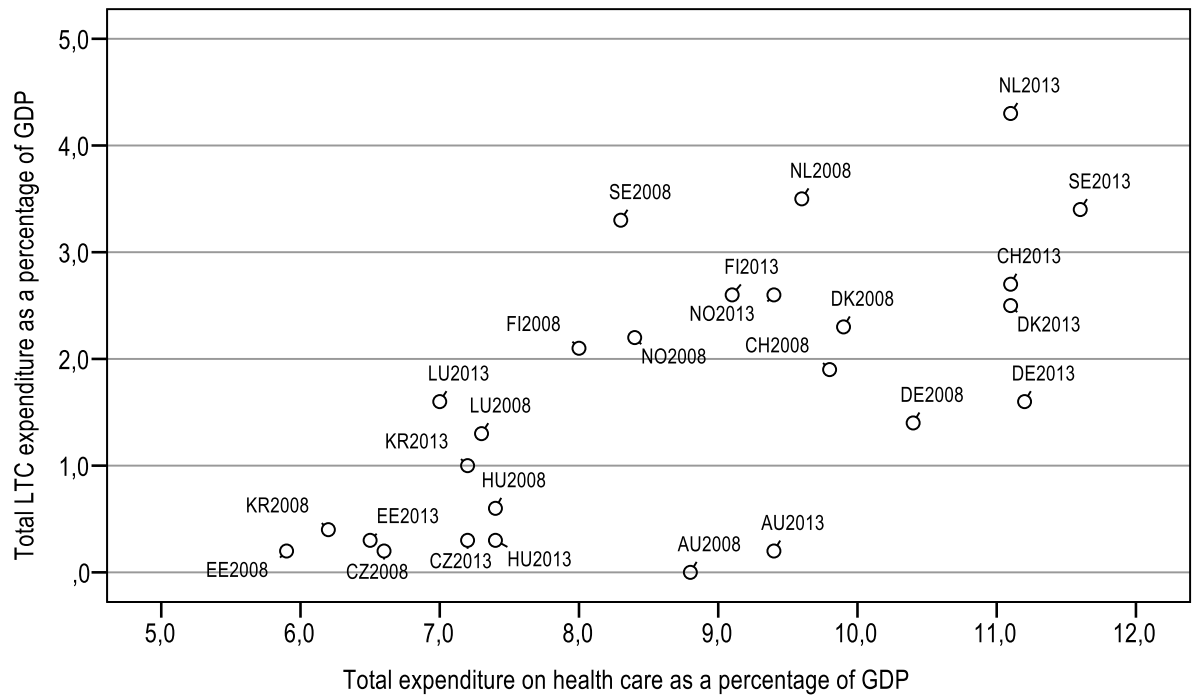

Source: authors based on OECD (2015b) 
Figure 2 shows that the Netherlands and Switzerland (where health care is financed from mandatory public health insurance) and Sweden and Denmark (where health care is financed from taxes) reach the largest volume of total expenditures on health care. These countries also allocate a larger volume of total expenditures on long-term care. By contrast, countries with low total expenditures on health care also allocated a lower volume of total expenditures on long-term care (e.g. Korea, Estonia, Czech Republic, Hungary). Statistical assessment through correlation coefficients would be misleading due to graphic heteroscedasticity when increasing expenditures on health care correlate with the higher value dispersion of expenditures on long-term care. It is mainly Australia that represents an exception, where health care is paid from taxes (Beveridge National Health Service model) and an above-average volume of total expenditures on health care (approximately 9\% of GDP) is reached, but there are minimum expenditures on long-term care services. Germany, where the health-care system is based on public (mandatory) health insurance, is also among countries with the highest total expenditures on health care (approximately $10.8 \%$ of GDP) but only average total expenditures on long-term care services (approximately $1.5 \%$ of GDP).

According to Colombo et al (2011, p. 214), the formal LTC sector in OECD countries is still relatively small (as a share of GDP), especially when compared to the estimated value of family care and expenditure on health or pension systems. Long-term care expenditure - particularly public LTC spending - has shown a faster upward trend than health care spending. Diverse priorities in financing can be observed in the volume of expenditures allocated to health care and long-term care in OECD countries.

\section{Structure of expenditures and recipients of long-term care in selected OECD countries}

With respect to a different historical development of health and social service systems and forms of provision and financing long-term care, differences both in the volume of expenditures on long-term care and in their structure can be observed in the selected OECD countries in the years 2008 and 2013 (Table 2).

From the set of OECD countries, in 2008 and 2013, expenditures on long-term care that accounted for the highest share on total GDP were observed in Sweden and the Netherlands. In other Nordic countries (Norway, Finland, Denmark) and Switzerland, expenditures accounted for more than $2.3 \%$ GDP. On the contrary, Estonia, Hungary, and Czech Republic, along with economically less developed OECD countries, such as Korea, allocated relatively low expenditures on long-term care (0.2-1.0\% GDP). In OECD countries, long-term care is generally financed from public resources. This is associated with the form of financing long-term care as well as taxing (composite tax quota) in the individual countries. Of all OECD countries, Denmark bears the largest tax burden (with the income of public budgets accounting for 50.8\% of the GDP). Aboveaverage taxing is also present in Sweden, Finland, Norway or the Netherlands, as opposed to countries with the lowest taxing, such as Korea, Estonia or the Czech Republic. In Germany and Switzerland, long-term care was financed from public resources (public long-term care insurance models in Germany, and mixed systems of LTC coverage based on a mix of universal and means-tested benefits in Switzerland), but private resources also contributed significantly, comprising 50-60\% of expenditures on long-term care. 
The majority of expenditures are allocated to institutional care, although users generally prefer home care. Furthermore, the countries have seen a change in their approaches, leading to the deinstitutionalisation of long-term care (Yeandle, Kroger \& Cass, 2012, Lewis \& West, 2014, Anttonen \& Karsio, 2016, Kubalčíková \& Havlíková, 2016), and new programmes of home-care support or of community and field services have been created. This is with the exception of Nordic countries (Denmark, Norway and Sweden), where emphasis was put on funding home care as well.

Table 2 Expenditure of long-term care in the selected OECD Countries for 2008 and 2013

\begin{tabular}{|c|c|c|c|c|c|c|c|c|c|c|c|c|}
\hline \multicolumn{13}{|c|}{ Expenditure of long-term care (\% GDP) } \\
\hline \multirow[b]{2}{*}{$\begin{array}{l}\text { Yearl } \\
\text { Coun- } \\
\text { try }\end{array}$} & \multicolumn{2}{|c|}{ Public } & \multicolumn{2}{|c|}{ Private } & \multicolumn{2}{|c|}{$\begin{array}{l}\text { LTC nurs- } \\
\text { ing care }\end{array}$} & \multicolumn{2}{|c|}{$\begin{array}{c}\text { Social } \\
\text { services of } \\
\text { LTC }\end{array}$} & \multicolumn{2}{|c|}{$\begin{array}{l}\text { Institutional } \\
\text { care }\end{array}$} & \multicolumn{2}{|c|}{ Home care } \\
\hline & 08 & 13 & 08 & 13 & 08 & 13 & 08 & 13 & 08 & 13 & 08 & 13 \\
\hline $\mathrm{AU}$ & 0 & 0.2 & 0 & 0 & 0 & 0.2 & 0 & 0 & 0 & 0.2 & 0 & 0 \\
\hline $\mathrm{CZ}$ & 0.2 & 0.3 & 0 & 0 & 0.2 & 0.3 & 0 & 0 & 0.2 & 0.2 & 0 & 0.1 \\
\hline $\mathrm{DE}$ & 0.9 & 1.0 & 0.5 & 0.6 & 1.3 & 1.5 & 0.1 & 0.1 & 0.9 & 1.0 & 0.4 & 0.5 \\
\hline DK & 2.1 & 2.3 & 0.2 & 0.2 & 2.3 & 2.5 & 0 & 0 & 1.0 & 1.1 & 1.3 & 1.4 \\
\hline $\mathrm{EE}$ & 0.2 & 0.2 & 0 & 0.1 & 0.2 & 0.3 & 0 & 0 & 0.2 & 0.3 & 0 & 0 \\
\hline $\mathrm{FI}$ & 1.8 & 2.2 & 0.3 & 0.4 & 0.9 & 0.8 & 1.2 & 0 & 0.8 & 0.7 & 0.1 & 0.1 \\
\hline $\mathrm{HU}$ & 0.3 & 0.2 & 0.3 & 0.1 & 0.3 & 0.3 & 0.3 & 0 & 0.3 & 0.3 & 0 & 0 \\
\hline $\mathrm{CH}$ & 1.3 & 1.8 & 0.6 & 0.9 & 1.9 & 2.2 & 0 & 0.5 & 1.7 & 1.9 & 0.2 & 0.3 \\
\hline $\mathrm{KR}$ & 0.3 & 0.7 & 0.1 & 0.3 & 0.4 & 1.0 & 0 & 0 & 0.4 & 0.9 & 0 & 0.1 \\
\hline LU & 1.1 & 1.3 & 0.2 & 0.3 & 1.3 & 1.5 & 0 & 0.1 & 0.8 & 1.0 & 0.4 & 0.5 \\
\hline NL & 3.5 & 4.3 & 0 & 0 & 2.4 & 2.9 & 1.1 & 1.4 & 2.0 & 2.4 & 0.4 & 0.5 \\
\hline NO & 2.0 & 2.4 & 0.2 & 0.2 & 2.2 & 2.6 & 0 & 0 & 1.4 & 1.6 & 0.8 & 1.0 \\
\hline SE & 3.3 & 3.2 & 0 & 0.1 & 0.7 & 2.8 & 2.6 & 0.6 & 1.8 & 2.0 & 0.8 & 0.9 \\
\hline
\end{tabular}

Note: 08 - data for 2008, 13 - data for 2013

Source: OECD (2015b)

The individual OECD countries also vary regarding the health and social components of LTC expenditures (Table 2). In countries such as Denmark, Norway, Luxembourg, Estonia and others, expenditures of long-term care contain only the health component (expenditures of long-term nursing care). On the other hand, in the Netherlands, Sweden, Finland or Switzerland, expenditures of long-term care are represented by both the health component (expenditures of long-term nursing care) and the social component (expenditures of social services of long-term care). According to OECD (2007), total expenditures on long-term care should include both expenditures on health services of long-term care as well as expenditures on social services provided in connection with long-term care. According to OECD, the differences can be associated with the delinea- 
tion of the border between health-care and social-care services, and statistical data in the individual countries. These discrepancies can have an effect on the international comparability of the key indicator: the share of expenditures on health-care on the country's GDP.

Demography development and population ageing are expected to put pressure on resources required to provide long-term care services for the frail elderly, and the ratio of long-term care expenditure to GDP is expected to rise in the future. Table 3 shows the structure of long-term care recipients in the selected OECD countries in the years 2008 and 2013, by institutional and home care and the structure of recipients aged $65+$ and $80+$.

Table 3 Long-term care recipients in the selected OECD Countries for 2008 and 2013

Long-term care recipients

\begin{tabular}{|c|c|c|c|c|c|c|c|c|c|c|c|c|}
\hline \multirow[b]{3}{*}{ Country/year } & \multicolumn{4}{|c|}{$\begin{array}{l}\text { LTC recipients } \% \text { of } \\
\text { total population }\end{array}$} & \multicolumn{4}{|c|}{$\begin{array}{l}\text { LTC recipients in institu- } \\
\text { tions } \% \text { of total population }\end{array}$} & \multicolumn{4}{|c|}{$\begin{array}{l}\text { LTC recipients at home } \\
\% \text { of total population }\end{array}$} \\
\hline & \multicolumn{2}{|c|}{ Aged $65+$} & \multicolumn{2}{|c|}{ Aged 80+ } & \multicolumn{2}{|c|}{ Aged 65+ } & \multicolumn{2}{|c|}{ Aged 80+ } & \multicolumn{2}{|c|}{ Aged 65+ } & \multicolumn{2}{|c|}{ Aged 80+ } \\
\hline & 08 & 13 & 08 & 13 & 08 & 13 & 08 & 13 & 08 & 13 & 08 & 13 \\
\hline $\mathrm{AU}$ & 13.9 & 15.0 & $36: 1$ & 39.5 & $7: 1$ & $6: 6$ & 20.7 & 20.2 & 6.8 & 8.4 & 15.4 & 19.3 \\
\hline$C Z$ & 13.2 & 13.2 & 36.0 & 36.0 & 1.9 & 2.2 & 5.5 & 6.5 & 11.3 & 11.0 & 30.5 & 29.5 \\
\hline DE & 10.8 & 12.4 & 29.6 & 31.3 & 3.7 & 4.0 & 11.7 & 11.3 & 7.1 & 8.4 & 17.9 & 20.0 \\
\hline DK & 19.0 & 15.6 & 51.3 & 46.7 & 4.9 & 4.0 & 13.9 & 12.7 & 14.1 & 11.6 & 37.4 & 34.0 \\
\hline EE & 8.5 & 6.0 & 18.4 & 12.2 & 1.8 & 2.2 & 4.5 & 5.0 & 6.7 & 3.8 & 13.9 & 7.2 \\
\hline $\mathrm{FI}$ & 12.0 & 11.8 & 31.2 & 31.1 & 4.7 & 4.7 & 12.8 & 12.8 & 7.3 & 7.1 & 18.4 & 18.5 \\
\hline $\mathrm{HU}$ & 9.3 & 13.5 & 15.8 & 21.7 & 2.9 & 3.0 & 6.5 & 7.1 & 6.4 & 10.5 & 9.3 & 14.6 \\
\hline $\mathrm{CH}$ & 19.1 & 20.3 & 46.0 & 49.9 & 6.5 & 6.1 & 18.3 & 17.5 & 12.6 & 14.2 & 27.7 & 32.4 \\
\hline KR & 2.8 & 6.5 & 8.9 & 19.0 & 1.1 & 2.4 & 3.9 & 7.9 & 1.7 & 4.1 & 5.0 & 11.1 \\
\hline LU & 12.1 & 13.4 & 32.1 & 33.0 & 4.9 & 5.5 & 15.4 & 16.0 & 7.2 & 7.9 & 16.7 & 17.0 \\
\hline $\mathrm{NL}$ & 19.8 & 18.1 & 49.9 & 47.5 & 6.7 & 5.6 & 19.5 & 16.8 & 13.1 & 12.5 & 30.4 & 30.7 \\
\hline NO & 18.0 & 16.8 & 41.4 & 41.9 & 5.5 & 4.9 & 14.2 & 13.8 & 12.5 & 11.9 & 27.2 & 28.1 \\
\hline SE & 17.4 & 16.3 & 38.7 & 43.7 & 6.0 & 4.9 & 15.7 & 14.1 & 11.4 & 11.4 & 23.0 & 29.6 \\
\hline
\end{tabular}

Note: 08 - data for 2008, 13 - data for 2013

Source: OECD (2016a)

In the years 2008 and 2013, the lowest share of LTC recipients (\% of the population) aged 65+ and 80+ were observed in Korea and Estonia, LTC recipients in institutions aged 65+ in Korea, Estonia, Hungary and the Czech Republic, and LTC recipients in institutions aged 80+ mainly in Estonia and the Czech Republic. By contrast, the highest share of LTC recipients in institutions aged 65+ and 80+ was observed in Australia. In Australia, recipients of institutional care and home care services under the health and community care program make a financial contribution to the cost of their care. In the 
years 2008 and 2013, a growing tendency of LTC recipients in institutions aged 65+ and $80+$ was observed, mainly in countries with a low share of LTC users (Korea, Estonia, Czech Republic, Hungary). Demographic changes and population ageing will mean that the development of long-term care continues to be in focus in the upcoming years, which will have an impact on the number of those receiving LTC. In connection with the sustainability of LTC systems, however, trends of LTC services in developed countries lead to the deinstitutionalisation and limitation of expenditures as well as the number of institutional care recipients. In the studied set of countries, a falling tendency of LTC recipients in institutions in 2008 and 2013 can be observed mainly in the Netherlands, Denmark, Sweden, Norway and Switzerland.

An evaluation of the similarities and differences of OECD countries' long-term-care indicators

Using TwoStep cluster analysis, the individual clusters of the selected set of OECD countries in the years 2008 and 2013 are analysed with respect to four indicators of long-term care: total LTC expenditure as a percentage of GDP, LTC expenditure on institutions as a percentage of total LTC expenditure, LTC recipients in institution as a percentage of total recipients, total number of LTC recipients aged 65+ as a percentage of total LTC recipients. The quality of the model was assessed (using a silhouette coefficient) for three clusters with four variables - indicators of long-term care reach 0.6. Clusters were generated using two-step cluster analysis (see Figure 3).

Figure 3 Box-plot of clusters of the selected OECD countries by selected long-term care variables for 2008 and $2013^{\mathrm{a}}$

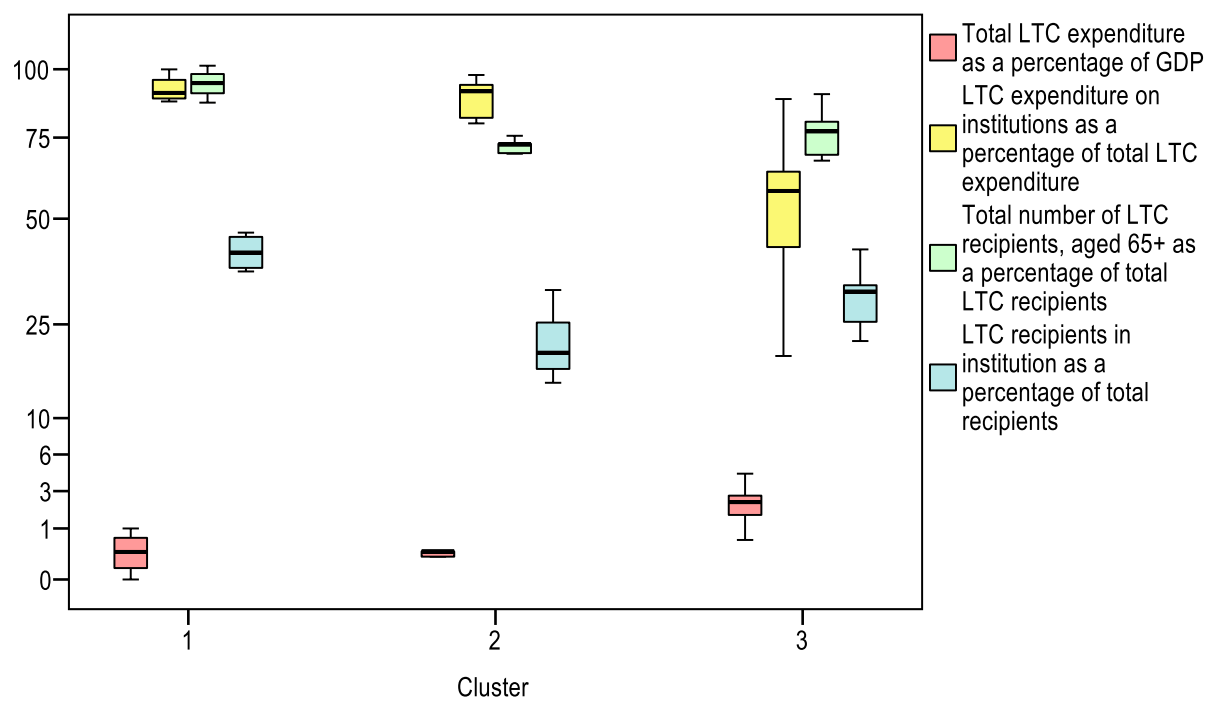

Note ${ }^{a}$ Power scale with exponent 0.5 on axis y

Source: authors, based on OECD $(2015 b, 2016 a)$ 
Cluster 1 (AU 2008, AU 2013, KR 2008, KR 2013) is the smallest in the representation of OECD countries by the given indicators of long-term care. It has the lowest total LTC expenditures as a percentage of GDP (mean value of 0.4) and the highest LTC expenditures on institutions as a percentage of total LTC expenditures (mean value of 92.4), as well as the highest total number of LTC recipients aged 65+ as a percentage of total LTC recipients (mean value of 94.5) and LTC recipients in institution as a percentage of total recipients (mean value of 41.2).

Cluster 2 (CZ 2008, CZ 2013, EE 2008, EE 2013, HU 2013) is represented by countries which, similarly to those in the first cluster, have the lowest total LTC expenditures as a percentage of GDP (mean value of 0.2) and higher LTC expenditures on institutions as a percentage of total LTC expenditures (mean value of 89). Compared to countries in the first cluster, countries in the second cluster typically reach the lowest values with a wider dispersion, mainly LTC recipients in institutions as a percentage of total recipients (mean value of 21.8) and the widest dispersion of values, ranging from 14.86 CZ2008 to 32.18 EE2013). Countries in the second cluster also reach lower values in the total number of LTC recipients aged 65+ as percentage of total LTC recipients than countries in the first and third cluster.

Cluster 3 represents the largest set of countries (DK 2008, DK 2013, FI 2008, FI 2013, DE 2008, DE 2013, HU 2008, CH 2008, CH 2013, LU 2008, LU 2013, NL 2008, NL 2013, NO 2008, NO 2013, SE 2008, SE 2013). The third cluster has a higher total number of LTC recipients aged 65+ as percentage of total LTC recipients (mean value of 76.8 and dispersion of values from 67.38 in NO2013 to 90.48 in DK2013) and the highest total LTC expenditures as a percentage of GDP (mean value of 2.35 and dispersion from 0.60 in HU2008 to 4.30 in NL2013). Compared to the countries in the first and second cluster, the third cluster of countries demonstrates the widest dispersion of values in all observed indicators. In the case of LTC expenditures in institutions as a percentage of total LTC expenditures, it is with a mean value of 54.3 (dispersion of values from 19.19 in SE2008 to 88.67 in CH2008), and in case of the share of LTC recipients in institutions as a percentage of total recipients, it is with a mean value of 30.78 (dispersion of values from 21.84 in NO2013 to 41.84 in FI2013).

The comprehensive comparison of indicators of long-term care shows that countries in the first and second cluster are the most similar in financing long-term care (total LTC expenditure as a percentage of GDP and LTC expenditures on institutions as a percentage of total LTC expenditures). Countries in the second and the third cluster are the most similar in the provision of long-term care by recipients (total number of LTC recipients aged $65+$ as a percentage of total LTC recipients, LTC recipients in institutions as a percentage of total recipients). Conversely, countries in the first and second cluster demonstrate the most marked differences in the provision of long-term care by recipients (total number of LTC recipients aged 65+ as a percentage of total LTC recipients, LTC recipients in institutions as a percentage of total recipients) and countries in the first and third cluster the most marked differences in financing care by LTC expenditures on institutions as a percentage of total LTC expenditures. 


\section{Discussion}

An assessment of selected indicators of long-term care of 13 OECD countries in the years 2008 and 2013 was conducted using TwoStep cluster analysis. Results showed that the most marked differences in the provision of long-term care by total number of LTC recipients aged $65+$ as a percentage of total LTC recipients and LTC recipients in institutions as a percentage of total recipients were found between the first cluster (AU, $\mathrm{KR}$, with the largest share of LTC recipients) and the second cluster (CZ, EE, with the smallest share of LTC recipients aged $65+$ and LTC recipients in institutions as a percentage of total LTC recipients). In the financing of long-term care (by LTC expenditure on institutions as a percentage of total LTC expenditure), the most notable differences were found between the first and third cluster. These differences are caused, according to Colombo et al. (2011) and Gori, Fernandez \& Wittenberg (2015), not only by different approaches to the financing of long-term care (beginning with the support of family solidarity in care for the long-term ill and ending with the provision of public services financed from public budgets), but also by differences in care needs, in the structure and comprehensiveness of formal LTC systems, and in family roles and caring culture. This fact can be seen in connection with the financing of long-term care in Korea (in the countries in the first cluster), which implemented a universal LTC insurance system in 2008 and whose population is rapidly ageing - spending is low but expected to grow in the future.

According to Colombo et al. (2011), public long-term care insurance models typically finance health care via social health insurance. These models are characterised by separate funding channels for LTC and health insurance, although they follow the same social-insurance model. Participation in the scheme is mandatory for the entire population or a large part. The scheme is predominantly financed through employment-based, payroll contributions, but seniors may also be asked to pay contributions, and in most countries, a share of the cost is funded out of general taxation. Among other countries that apply this form of financing of long-term care are Germany, the Netherlands and Luxembourg. Mainly Nordic countries - Norway, Sweden, Denmark, and Finland (countries in the third cluster) implement universal LTC coverage within a single programme - tax-based models provide universal, tax-funded long-term care services as an integral component of welfare and health-care services for the entire population. Public long-term care services in these countries are extensive and comprehensive, resulting in a relatively large share of GDP spent on LTC - ranging from $2.2 \%$ in Denmark to $3.3 \%$ in Sweden. Financing of long-term care from public resources also includes mixed systems of LTC coverage which are provided through a mix of different universal programmes and benefits operating alongside one another, or a mix of universal and means-tested LTC entitlements (e.g. in the Czech Republic, Australia, Switzerland). Options of financing long-term care are further dealt with, for instance, in Colombo et al. (2011, pp. 213-229).

In terms of research already carried out, long-term care from the viewpoint of the provision and financing in OECD countries was tackled by, for instance, Colombo et al. (2011), an evaluation of long-term care in the context of public spending in selected European countries was carried out by Repková et al. (2011), or Lipszyc, Sail \& Xavier (2012), who analysed public expenditures on long-term care as a percentage of GDP and public expenditures by the type of provider in 27 EU countries in 2010. In a wider 
context, Kraus et al. (2010) dealt with LTC by assessing seven variables (indicators) regarding the use and financing of long-term care of the formal and informal sector by using cluster analysis for 14 EU countries. In terms of both of the indicators (LTC expenditure as \% of GDP, recipients of LTC aged 65+ as a share of the population aged 65+) and the countries analysed (DE, DK, FI, SE, NL, EE, CZ, HU), which were included in the present research, authors reached similar results. Other authors, namely Mot et al. (2012), dealt with the relationship between the typology of LTC systems and the use and financing of care in 13 EU countries using correlation analysis, and assessed identical LTC indicators as Kraus et al. (2010).

The issue discussed in connection with the financial sustainability of long-term care in all countries are demographic trends connected with ageing of the population (Werblow, Felder \& Zweifel, 2007, Fernández \& Forder, 2010, Šoltés \& Gavurová, 2014, Rodrigues, 2015, Rowles \& Teaster, 2016). In relation to this issue, Válková, Kojesová \& Holmerová (2010) argue that costs on LTC are relatively low compared to other expenses that are a consequence of age-related demographic changes, and LTC costs have not significantly increased. Similarly, Rodrigues (2015, p. 6) also argues that public expenditures on long-term care (LTC) as a percentage of GDP remain relatively low, compared to expenditures on healthcare or other forms of age-related social protection (e.g. old-age pensions), and are highly differentiated between countries. Demographic ageing has, however, raised concerns about the future levels of public expenditure and the financial sustainability of current LTC. According to La Maisonneuve \& Oliveira Martins (2013a, 2013b, p. 25), "Differences in health care and long-term care spending emerge across OECD countries partly reflecting differing demographic trends (the number of dependent people in the population, the evolution of life expectancy) as well as initial levels of income, changes in the demand for public-financed LTC services and informal long-term care supply." Korea, for example, is projected to experience above average increases in public health expenditures. By contrast, Nordic countries are to display lower than average growth over the next 50 years. These projected trends in public health and long-term care spending are likely to be a major source of concern for most governments.

Figure 4 Share of population aged 80+ in selected OECD Countries

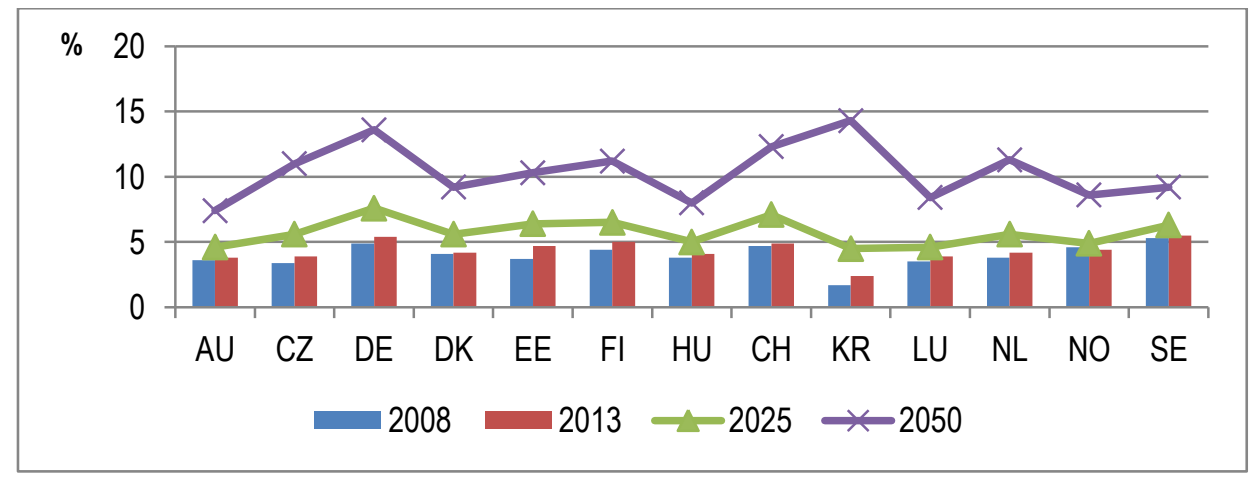

Source: Authors based on OECD (2016b) 
Repková et al. (2011) also argues that the rise in people aged 80+ (Figure 4), who will require LTC services to a larger extent, will result in growing expenditures on LTC not only in absolute terms but also in terms of percentage (of GDP). According to the OECD (2015a), public spending on health and long-term care in OECD countries is set to increase from around 6\% of GDP today to almost 9\% of GDP in 2030.

As a result, mainly countries with an increased rate of population ageing and with a low level of LTC systems should pay more attention to tackling long-term care. Ageing, however, is not the only factor to have an impact on growing public expenditures. As Colombo \& al. (2011), Johansson, Long \& Parker (2011), Lipszyc, Sail \& Xavier (2012), Broese van Groenou \& De Boer (2014) and Gavurová \& Šoltés (2016) argue, changes in the position and role of families are bound to take place. In some countries, long-term-care needs are almost exclusively satisfied by means of informal care, mainly family carers. The development of professional services may therefore lead to a significant rise in public spending.

Horecký (2014, p. 32) also claims that all countries tackle the sustainability of their LTC systems, from the viewpoint of both financial and personal resources. Increases in costs result from a higher number of people in need of care (not only with respect to population ageing - negative population growth - but also due to the increasing number of people with health problems). According to Horecký (2014) or Repková et al. (2011), countries are seeking satisfactory, rational solutions, such as stronger emphasis on informal care, supporting volunteers and help of neighbours, or delegating competences and responsibility to regional level and administrative units. The authors agree that to assure the long-term sustainability of LTC systems, all its forms will have to be maintained in the future.

\section{Conclusion}

Systems of long-term care show health-care and social services developing differently, and also being influenced by economic, social, demographic and cultural factors of individual countries. The specific nature of long-term care systems is associated with the structure and extent of the formal system, but also the form of long-term care's financing (from supporting family solidarity in caring for the long-term ill to providing public services financed from public budgets). In OECD countries, financing of longterm care from public resources utilises tax-based models which provide universal, taxfunded long-term care services as an integral component of welfare and health-care services for the entire population. Public long-term care insurance typically finances health care via social health insurance and mixed systems of LTC coverage, which is provided through a mix of universal programmes and benefits operating alongside one another, or a mix of universal and means-tested LTC entitlements. Private voluntary insurance plays an important supplementary role in financing additional costs of care or allowing individuals with different preferences to be financed outside of the public system.

The aim of this paper was to assess forms of providing and financing long-term care based on the volume and structure of long-term care expenditures in 13 OECD countries. Results of the evaluation carried out for the years 2008 and 2013 by means of the selected indicators of long-term care using two-step cluster analysis confirmed similar as 
well as different approaches to the provision and financing of long-term care among the analysed countries. The most marked differences in the provision of long-term care by LTC recipients were observed in the first cluster (Australia and Korea with the highest share of LTC recipients aged 65+ and Australia with the highest share of LTC recipients in institutions as a percentage of total LTC recipients) and the second cluster (Czech Republic, Estonia, with the lowest share of LTC recipients in institutions and LTC recipients aged $65+$ as a percentage of total LTC recipients). In financing long-term care (by LTC expenditures on institutions as a percentage of total LTC expenditures), the most marked differences were proved between the first (Australia, Korea, with the largest share of LTC expenditures on institutions of total LTC expenditures) and the third cluster (mainly Nordic countries Sweden, Denmark, Finland, with the lowest share of LTC expenditures on institutions as a percentage of total LTC expenditures).

Population ageing and the development of professional services of long-term care will result in a significant rise in public expenditures. Mainly countries with a rapid growth in the number of people aged $80+$ will have to address the problem of long-term-care systems' sustainability, and will seek other forms of procuring relevant services within the formal and informal sector. As a result, questions associated with the provision and financing of long-term care remain open as to the users' needs against the quality of the service, or emphasis on informal care and family solidarity. These questions may serve as a topic for further research.

Funding: This work was supported through the Operational Programme Education for Competitiveness - Project No.CZ.1.07/2.3.00/20.0296 and Evaluation of Public Policy Objectives in the Context of Sustainable Development and Performance of Regions Project No. RO/2016/08.

Disclosure statement: No potential conflict of interest was reported by the authors.

\section{References}

ANTTONEN, A. \& SIPILA, J. (1996). European social care services: Is it possible to identify models? Journal of European Social Policy. 9(2), pp. 87-100. DOI: $10.1177 / 095892879600600201$.

ANTTONEN, A. \& KARSIO, O. (2016). Eldercare Service Redesingn in Finland: Deinstitutionalization of Long-Term care. Journal of Social Service Research. 42(2), pp. 151-166. DOI:10.1080/01488376.2015.1129017

BARR, N. (2010). Long-term care: A suitable case for social insurance. Social Policy and Administration. 44 (4), pp. 359-374. DOI: 10.1111/j.1467-9515.2010.00718.X

BRENNAN, D., CASS, B., HIMMELWEIT, S., \& SZEBEHELY, M. (2012). The marketisation of care: Rationales and consequences in Nordic and liberal care regimes. Journal of European Social Policy. 22(4), pp. 377-391. DOI: $\underline{10.1177 / 0958928712449772}$ 
BROESE VAN GROENOU, M. I. \& DE BOER, A. (2014). Providing informal care in a changing society. European Journal of Ageing. 13(3), pp. 271-279. DOI: 10.1007/s10433-016-0370-7

COLOMBO, F., LLENA-NOZAL, A., MERCIER, J. \& TJADENS, F. (2011). Help Wanted? Providing and Paying for Long-Term Care. OECD Health Policy Studies. Paris: OECD. DOI: 10.1787/9789264097759-en

DANDI R. \& CASANOVA, G. (2012). Quality Assurance Indicators of Long-Term Care in European Countries. ENEPRI Research Report No. 110. Brussels: Centre for European Policy Studies.

DE LA MAISONNEUVE, C. \& OLIVEIRA MARTINS, J. (2013a). A Projection Method for Public Health and Long-term Care Expenditures. OECD Economics Department Working Papers No. 1048. Paris: OECD Publishing. DOI: $10.1787 / 5 \mathrm{k} 44 \mathrm{v} 53 \mathrm{w} 5 \mathrm{w} 47$-en

DE LA MAISONNEUVE, C. \& OLIVEIRA MARTINS, J. (2013b). Public Spending on Health and Long-Term Care: A New Set of Projections. OECD ECONOMIC POLICY PAPERS NO. 6. [Online]. June 2013. Available from: https://www.oecd.org/eco/ growth/Health\%20FINAL.pdf [Accessed: 15th October 2016]

DEUSDAD, B. A, PACE, CH. \& ANTTONEN A. (2016). Facing the Challenges in the Development of Long-Term Care for Older People in Europe in the Context of an Economic Crisis. Journal of Social Service Research. 42(2), pp. 144-150. DOI: $10.1080 / 01488376.2015 .1133147$

EUROPEAN COMMISSION (2009). The 2009 Ageing Report: Economic and Budgetary projections for the EU-27 Member States (2008-2060). Joint Report prepared by the European Commission (DG ECFIN) and the Economic Policy Committee (AWG). European Economy 2/2009. Brusels: European Commission. DOI: 10.2765/80301

EUROPEAN COMMISSION (2011). The 2012 Ageing Report: Underlying Assumptions and Projection Methodologies. Joint Report prepared by the European Commission (DG ECFIN) and the Economic Policy Committee (AWG). European Economy 4/2011 Brusels: European Commission. DOI: $\underline{10.2765 / 15373}$

EUROPEAN COMMISSION (2015). The 2015 Ageing Report Economic and budgetary projections for the 28 EU Member States (2013-2060).EUROPEAN ECONOMY 3|2015. Brusels: European Commission.

FERNANDEZ, J L. \& FORDER, J. (2010). Equity, efficiency, and financial risk of alternative arrangements for funding long-term care systems in an ageing society. $O x$ ford Review of Economic Policy. 26(4), pp. 713-733. DOI: 10.1093/oxrep/grq036

GAVUROVÁ, B. \& ŠOLTÉS, V. (2016). Economic aspects of social services development in Slovakia in the context of demographic changes. Scientific Papers of the University of Pardubice. 23 (37 (2/2016)), pp. 14-25.

GEERTS, J., WILLEMÉ, P. \& MOT, E. (eds.) (2012). Projecting Long-Term Care Use and Supply in Europe. ENEPRI Research Report No. 116. Brussels: Centre for European Policy Studies. 
GORI, C., FERNANDEZ, J L. \& WITTENBERG, R. (eds.) (2015). Long-Term Care Reforms in OECD Countries. Chicago: The University of Chicago Press.

HORECKÝ, J. (2014). Otázky dlouhodobé domácí péče v zemích EU. Sociální služby. 16(1), pp. 28-32.

JOHANSSON, L, LONG, H. \& PARKER, M. G. (2011). Informal Caregiving for Elders in Sweden: An Analysis of Current Policy Developments. Journal of Aging \& Social Policy. 23(14), pp. 335-353. DOI: 10.1080/08959420.2011.605630

KOŠTÁL, J. (2013). Vybrané metody vicerozměrné statistiky (se zvláštním zaměrením na kriminologický výzkum). Praha: Institut pro kriminologii a sociální prevenci.

KRAUS, M., RIEDEL, M., MOT, E., WILlEMÉ, P., RÖHRLING, G. \& CZYPIONKA, T. (2010). A Typology of Long-Term Care Systems in Europe. ENEPRI Research Report No. 91. Brussels: Centre for European Policy Studies.

KUBALČÍKOVÁ, K. \&. HAVLÍKOVÁ, J. (2016). Current Developments in Social Care Services for Older Adults in the Czech Republic: Trends Towards Deinstitutionalization and Marketization. Journal of Social Service Research. 42(2), pp. 180-198. DOI : $\underline{10.1080 / 01488376.2015 .1129014 .}$

LEWIS, J. \& WEST, A. (2014). Re-Shaping Social Care Services for Older People in England: Policy Development and the Problem of Achieving „Good Care“. Journal of Social Policy. 43 (01), pp. 1-18. DOI: 10.1017/S0047279413000561

LIPSZYC, B., SAIL, E. \& XAVIER, A. (2012). Long-term care: Need, use and expenditure in the EU-27. EUROPEAN ECONOMY, Economic Papers 469. Brussels: European Commission

MAZZOCCHI, M. (2008). Statistics for Marketing and Consumer Research. London: Sage Publications.DOI: 10.4135/9780857024657

MELOUN, M \& MILITKÝ, J. (2004). Statistická analýza experimentálních dat. 2nd edition. Prague: Academia.

MERTL, J. (2010). Achilles' Heels of Health Care Systems. Národohospodářský obzor/Review of Economic Perspectives. 10(1), pp. 21-40. DOI: 10.2478/v10135-009$\underline{0007-2}$

MOT, E., FEBER, R., GEETS, J. \& WILLEME, P. (2012). Performance of Long-Term Care Systems In Europe.ENEPRI Research Report No. 117. Brussels: Centre for European Policy Studies.

MUISER, J. \& CARRIN, G. (2007). Financing long-term care Programmes in Health Systems- with a Situation Assessment in Selected high-, middle- and low-Income Countries. Discussion Paper number 6. Geneva: World Health Organization.

OECD (2005). Long-term Care for Older People. Paris: OECD.

OECD (2007). Conceptual framework and methods for analysis of data sources for long-term care expenditure. Final report. [Online]. December 2007.Available from: https://www.oecd.org/els/health-systems/Conceptual\%20Framework\%20and\%20 
Methods\%20for\%20Analysis\%20of\%20Data\%20Sources\%20for\%20Long-

Term\%20Care\%20Expenditure.pdf. [Accessed: 15th October 2016],

OECD (2015a). Fiscal Sustainability of Health Systems. Bridging Health and Finance Perspectives. Paris: OECD. DOI: 10.1787/9789264233386-en

OECD (2015b). Health expenditure and financing. [Online]. December 2015. Available from: http://stats.oecd.org/Index.aspx?DatasetCode=HEALTH_STAT\# [Accessed: 20th May 2016].

OECD (2016a). Long-Term Care Resources and Utilisation: Long-term care recipients [Online]. January 2016. Available from: http://stats.oecd.org/Index.aspx? ?atasetCode= HEALTH_STAT [Accessed: 15th Jun 2016].

OECD (2016b). Population. [Online]. Jauary 2016. Available from http://stats.oecd. org/Index.aspx? ? DatasetCode=POP_FIVE_HIST [Accessed: 15th Jun 2016].

ÖSTERLE, A. (2010). Long-term Care in Central and South-Eastern Europe: Challenges and Perspectives in Adressing a „New“ Social Risk. Social Policy \& Administration. 44 (4), pp. 461-480. DOI: $\underline{10.1111 / \mathrm{j} .1467-9515.2010 .00723 . \mathrm{x}}$

PAVOLINI, E. \& RANCI, C. (2008). Restructuring the welfare state: reforms in longterm care in Western European countries. Journal of European Social Policy. 18 (3), pp. 246-259. DOI: $\underline{10.1177 / 0958928708091058}$

PRŮŠA, L. (2011). Model of effective financing and providing of long-term care. Praha: Výzkumný ústav práce a sociálních věcí.

REPKOVÁ, K. \& al. (2011). Dlhodobá starostlivost' o staršich ludí na Slovensku a v Európe (3): Správa, riadenie a financovanie. Bratislava: Inštitút pre výzkum práce a rodiny.

RODRIGUES, R. (2015). Long-term care - the problem of sustainable financing. Luxembourg: European Commission.

ROWLES, G. D. \& TEASTER, P. B. (eds.) (2016). Long-Term Care in an Aging Society: Theory and Practice. New York: Springer.

ŘEZANKOVÁ, H. \& LÖSTER, T. (2013). Shluková analýza domácností charakterizovaných kategoriálními ukazateli. E \&M Economics and Management. 6(3), pp. 139147.

ŠOLTÉS,V. \& GAVUROVÁ, B. (2014). Analysis of Selected Demographic Aspects of Day Surgery in Slovak Health Policy. Journal of Applied Economic Sciences. 9 (3(29)), pp. 477-487.

VÁlKOVÁ, M., KOJESOVÁ, M. \& HOLMEROVÁ, I. (2010). Diskusni materiál $k$ východiskuim dlouhodobé péče v ČR. Praha: MPSV ČR.

WERBLOW, A., FELDER, S. \& ZWEIFEL, P. (2007). Population Ageing and Health Care Expenditure: A School of Red Herrings?. Health Economics. 16(10), pp. 11091126. DOI: $\underline{10.1002 / \text { hec. } 1213}$

YEANDLE, S., KROGER, T., \& CASS, B. (2012). Voice and choice for users and carers? Developments in patterns of care for older people in Australia, England and 
REVIEW OF ECONOMIC PERSPECTIVES

Finland. Journal of European Social Policy. 22(4), pp. 432-445. DOI: $\underline{10.1177 / 0958928712449775}$ 